\title{
Medicinal Plants Extracts Impact on Oxidative Stress in Mice Brain under the Physiological Conditions: the Effects of Corn Silk, Parsley, and Bearberry
}

\author{
Marijana Vranješ, ${ }^{1}$ Dubravka Štajner, ${ }^{2}$ Dejan Vranješ, ${ }^{1}$ Bojana Blagojević, ${ }^{2,}$ \\ Ksenija Pavlović, ${ }^{3}$ Dubravka Milanov ${ }^{4}$ and Boris M. Popović ${ }^{2}$ \\ ${ }^{1}$ Emergency Centre, Clinical Centre of Vojvodina, Hajduk Veljkova 1, 21000 Novi Sad, Serbia \\ ${ }^{2}$ Chemistry and Biochemistry Laboratory, Department of Field and Vegetable Crops, Faculty of Agriculture, \\ University of Novi Sad, Trg Dositeja Obradovića 8, 21000 Novi Sad, Serbia \\ ${ }^{3}$ Department of Chemistry, Biochemistry and Environmental Protection, Faculty of Sciences, \\ University of Novi Sad, Trg Dositeja Obradovića 3, 21000 Novi Sad, Serbia \\ ${ }^{4}$ Scientific Veterinary Institute "Novi Sad", Rumenački put 20, 21113 Novi Sad, Serbia \\ *Corresponding author: E-mail: bojana.blagojevic@polj.uns.ac.rs
}

Received: 04-13-2021

\begin{abstract}
This study was performed to examine the effects of medicinal plant extracts of corn silk (Stigma maydis), parsley leaf (Petroselini folium), and bearberry leaf (Uvae ursi folium) on antioxidant status of the brain of experimental animals (mice) under the physiological conditions. Biological properties of these plants are insufficiently investigated and the aim was to explore their possible antioxidant effects that can alleviate oxidative damage of the brain tissue. Corn silk extract showed positive effect on activities of antioxidant enzymes in mice brain tissue. Parsley extract induced the increase in glutathione content and decrease of lipid peroxidation. Bearberry leaf extract induced catalase activity and decrease of hydroxyl radical content, while malonyldialdehide accumulation was maintained at the control level. Results obtained in this study support the use of corn silk, parsley and bearberry leaves as natural antioxidant sources in the prevention and treatment of brain tissue damages and different diseases caused by oxidative stress.
\end{abstract}

Keywords: corn silk; parsley; bearberry; brain; oxidative stress; antioxidants

\section{Introduction}

Oxidative stress is one of the biggest threats to brain cells because of their large oxygen consumption. ${ }^{1}$ Brain oxidative stress can be monitored primarily by superoxide and hydroxyl radical, hydrogen peroxide, other reactive oxygen species (ROS) and lipid peroxidation (LP) products. ${ }^{2}$ Moreover, brain damages caused by free radicals can lead to serious neurological disorders such as stroke, dementia, and Alzheimer's disease. ${ }^{3}$ Traumatic brain injuries (TBI) are followed by increased reactive species production and LP process that can further cause severe damages and fatal consequences. ${ }^{4}$ Human clinical trials still did not result in efficient neuroprotective therapies for TBI and this disorder is among the most severe health problems and causes of death worldwide. ${ }^{5}$
When nerve injury occurs, the first minutes and hours are critical because of the activation of numerous sources of superoxide anion radical $\left(\mathrm{O}_{2}{ }^{\circ-}\right)$. The brain, like the other organs in aerobic organisms, has potent defenses against superoxide, including enzymatic antioxidants such as superoxide dismutase (SOD), catalase (CAT), guaiacol peroxidase $(\mathrm{GPx})$, glutathione peroxidase $(\mathrm{GSH}-\mathrm{Px})$ and reduced glutathione as nonenzymatic antioxidant (GSH). ${ }^{6}$ By reduction of oxidative stress, they play important roles in neurotoxicity and neurological disorders. ${ }^{7}$

Over the last time period, the accent is given to the substances with antioxidant properties, designed to scavenge reactive species responsible for LP induction and its neurotoxic effects. ${ }^{4}$ Natural products can enhance antioxidant defense activities and minimize different tissue oxi- 
dative damages. ${ }^{8,9}$ It was shown that high dietary intake of some vitamins, carotenoids and flavonoids from food and medicinal plants can reduce the risk of Alzheimer's disease and exhibit a protective effect on neural tissue. ${ }^{10}$

Although the bioactive potential of corn silk (Stigma maydis), parsley leaf (Petroselini folium) and bearberry leaf (Uvae ursi folium) is insufficiently tested, these medicinal plants showed the antioxidative and protective roles in treatment and prevention of many diseases, especially renal diseases, nephritis, kidney stones, chronic cystitis, for weakened kidneys, liver or pancreas. ${ }^{11-13}$ The aim of this study was to explore their protective antioxidative and free radical scavenging effects that could prevent oxidative damage of the mice brain tissue.

\section{Experimental}

\section{1. Chemicals and Reagents}

Folin-Ciocalteau's reagent, guaiacol (2-methoxyphenol), NBT (Nitro Blue Tetrazolium), DPPH (2,2-diphenyl-1-picrylhydrazyl), TPTZ (2,4,6-tripyridyl-triazine), TBA (2-thiobarbituric acid), iron(III) chloride and potassium dihydrogen phosphate, methanol (HPLC gradient grade) and standard substances were obtained from Sigma-Aldrich (Belgrade, Serbia). All other reagents and chemicals were of analytical grade.

\section{2. Plant Extracts Preparation}

Corn silk (Stigma maydis; Zea mays L.), parsley leaf (Petroselini folium; Petroselinum crispum L.) and bearberry leaf (Uvae ursi folium; Arctostaphylos uva-ursi L.) originated from Serbia and were bought commercially (Dr. Josif Pančić Institute, Belgrade, Serbia). Dried plant material was ground into a fine powder and macerated in $96 \%$ ethanol $(1: 20, \mathrm{w} / \mathrm{v})$ for $72 \mathrm{~h}$ in the dark. Ethanol was evaporated under reduced pressure at $40{ }^{\circ} \mathrm{C}$. The yields (Y) of obtained extracts were $6.12 \%, 8.28 \%$ and $34.93 \%$ for corn silk, parsley leaves and bearberry leaves, respectively. Dry residues were redissolved in water to obtain 5\% (w/v) extracts.

\section{3. Experimental Animals}

Three months old male mice (Mus musculus, NMRI strain), weighing 31-46 g, were housed at the Department of Pharmacology, Toxicology and Clinical Pharmacology, Medical Faculty, University of Novi Sad, Serbia. Animals were handled in accordance with the European Union principles established for research on animal models (EU Directive 2010/63/EU) and Serbian national guideline (No. 41/09). Animals were bred at controlled temperature $\left(21 \pm 1{ }^{\circ} \mathrm{C}\right)$ and humidity $(55 \% \pm 1.5 \%)$, with $12 \mathrm{~h}$ day/12 $\mathrm{h}$ night cycle. They were fed standard laboratory mice feed, produced by the Veterinary Institute in Zemun,
Serbia. During the treatment, every animal was kept in a separate metabolic plexiglas cage. Ten animals were regarded as one group. The first group served as control and had ad libitum access to water and feed. Instead of water, animals in the other three groups were given appropriate plant extract: corn silk, parsley and bearberry leaf extract, respectively. After 28 days of the treatment, animals were sacrificed under urethane anesthesia. Brain tissue was removed and homogenized.

\section{4. Preparation of Brain Homogenate}

According to the method of Vranješ et al. ${ }^{13}$, after washing the brain tissue in saline solution, it was homogenized in $1.15 \%$ potassium chloride solution and $0.05 \mathrm{M}$ potassium phosphate buffer solution ( $\mathrm{pH} 7.4$ ) to yield $10 \%$ homogenate $(\mathrm{w} / \mathrm{v})$. The mixture was ultrasonicated for 15 minutes and then centrifuged 5 minutes at $4000 \times g$ and 4 ${ }^{\circ} \mathrm{C}$. Supernatants were kept at $-20{ }^{\circ} \mathrm{C}$ until analyses. Samples prepared as described were used for all assays except for those where it was differently stated (LP and GSH determinations).

\section{5. Assessment of Prooxidant / Antioxidant Activity}

The activity of the enzyme superoxide dismutase (SOD) was estimated by the ability of extract to inhibit photosensitive reduction of nitro blue tetrazolium chloride (NBT) reagent. ${ }^{14}$ Reaction medium was prepared by mixing $2.6 \mathrm{~mL}$ of $50 \mathrm{mM}$ phosphate buffer ( $\mathrm{pH} 7.8$ ), 100 $\mu \mathrm{L}$ of $13 \mathrm{mM}$ methionine, $100 \mu \mathrm{L}$ of $75 \mu \mathrm{M}$ NBT, $100 \mu \mathrm{L}$ of $0.1 \mathrm{mM}$ EDTA, and $50 \mu \mathrm{L}$ of $2 \mu \mathrm{M}$ riboflavin. Supernatant $(10-50 \mu \mathrm{L})$ was added in test samples, while the same volume of buffer was added for blanks (maximum formazan production). The absorbance was read at 560 $\mathrm{nm}$. The quantity of the enzyme needed for $50 \%$ inhibition of the NBT-formazan formation was expressed as one unit $(\mathrm{U})$. Final results were calculated as U per milligram of proteins.

Catalase (CAT) activity was determined by measuring the reduction of absorbance at $240 \mathrm{~nm}$, as a consequence of the degradation of $\mathrm{H}_{2} \mathrm{O}_{2} \cdot{ }^{15}$ Blank was prepared by mixing $50 \mu \mathrm{L}$ of supernatant and $3 \mathrm{~mL}$ of phosphate buffer $(0.05 \mathrm{M}, \mathrm{pH} 7)$. In test tubes there were mixed $50 \mu \mathrm{L}$ of supernatant, $2 \mathrm{~mL}$ of buffer and $1 \mathrm{~mL}$ of freshly prepared $\mathrm{H}_{2} \mathrm{O}_{2}(0.1 \%)$ was added to start the reaction. The quantity of the enzyme that degrades $1 \mu \mathrm{mol} \mathrm{H}_{2} \mathrm{O}_{2}$ in $1 \mathrm{~min}$ at $25^{\circ} \mathrm{C}$ was expressed as one unit (U).

Guaiacol peroxidase (GPx) activity was determined by transformation of guaiacol to tetraguaiacol. ${ }^{16}$ The change of absorbance was measured at $436 \mathrm{~nm}$. Superna$\operatorname{tant}(100 \mu \mathrm{L})$ was added to reaction medium containing 3 $\mathrm{mL}$ of phosphate buffer $(0.1 \mathrm{M}, \mathrm{pH} 7), 50 \mu \mathrm{L}$ of guaiacol solution (prepared by diluting $220 \mu \mathrm{L}$ of guaiacol in 100 $\mathrm{mL}$ of water) and $30 \mu \mathrm{L}$ of $12.3 \mathrm{mM} \mathrm{H}_{2} \mathrm{O}_{2}$. The one unit 
(U) is the GPx activity that transforms $1 \mu \mathrm{mol}$ of guaiacol to tetraguaiacol during $1 \mathrm{~min}$ at $25^{\circ} \mathrm{C}$.

The activity of glutathione peroxidase (GSH-Px) was assessed using cumene hydroperoxide and reduced glutathione $(\mathrm{GSH})$ as the substrate. ${ }^{17}$ Supernatant $(100 \mu \mathrm{L})$ was mixed with $700 \mu \mathrm{L}$ TRIS buffer (pH 7.6). After $5 \mathrm{~min}$ of incubation, $100 \mu \mathrm{L}$ of GSH (6 mg GSH dissolved in 10 $\mathrm{mL}$ TRIS buffer) and $100 \mu \mathrm{L}$ of cumene hydroperoxide (5 $\mu \mathrm{L}$ diluted in $10 \mathrm{~mL}$ TRIS buffer) were added. After $10 \mathrm{~min}$ of incubation, $20 \%$ trichloracetic acid (TCA) was added. The mixture was centrifuged for 5 minutes at $4000 \times g$ and $4{ }^{\circ} \mathrm{C}$. The volume of $1 \mathrm{~mL}$ of supernatant was mixed with $2 \mathrm{~mL}$ TRIS buffer and $100 \mu \mathrm{L}$ of $0.01 \mathrm{M}$ DTNB (5,5'-dithio-bis(2-nitrobenzoic acid) reagent was added. The GSHPx activity was determined by the absorbance change at $412 \mathrm{~nm}$ and expressed as U/mg protein. The quantity of the enzyme that catalyses the oxidation of $1 \mu \mathrm{mol}$ of GSH in $1 \mathrm{~min}$ at $25^{\circ} \mathrm{C}$ was expressed as one unit (U).

Soluble protein content was set by the method of Bradford. ${ }^{18}$ The Bradford reagent was prepared by dissolving $100 \mathrm{mg}$ of Coomassie Brilliant Blue G-250 in 3\% perchloric acid. The absorbance of the complex was read at $595 \mathrm{~nm}$. The calibration curve was prepared with bovine serum albumin.

For lipid peroxidation (LP), brain tissue (0.5 g) was homogenized with $4.5 \mathrm{~mL}$ of LP reagent. The LP reagent was composed of $0.5 \%$ thiobarbituric acid (TBA; prepared in $10 \% \mathrm{HClO}_{4}$ ) and $20 \% \mathrm{TCA}$, mixed in ratio $1: 3$. The homogenate was boiled at $100{ }^{\circ} \mathrm{C}$ for $30 \mathrm{~min}$, centrifuged for $10 \mathrm{~min}$ at $4000 \times \mathrm{g}$. The intensity of lipid peroxidation (LP) was expressed as the amount of malonyldialdehyde (MDA), which is one of the final products of lipid membrane degradation. ${ }^{19}$ The absorbances were read at $532 \mathrm{~nm}$ and $600 \mathrm{~nm}$, and the final absorbance was calculated as $\mathrm{A}_{532}-\mathrm{A}_{600}$. The results were expressed as nmol MDA/mg protein.

Power of the tissue antioxidant systems capable to scavenge hydroxyl radical was measured by the deoxyribose degradation test. ${ }^{20}$ In the reaction medium composed of $250 \mu \mathrm{L} \mathrm{mL}$ of $0.003 \% \mathrm{H}_{2} \mathrm{O}_{2}$ (diluted in $12 \mathrm{mM}$ phoshate buffer, pH 7.4), $250 \mu \mathrm{L}$ of $0.1 \mathrm{mM} \mathrm{FeSO}_{4}$, and $250 \mu \mathrm{L}$ of 10 $\mathrm{mM} 2$-deoxyribose, $500 \mu \mathrm{L}$ of supernatant was added. In control tubes, supernatant was replaced with buffer solution. The tubes were incubated for $30 \mathrm{~min}$ at $37^{\circ} \mathrm{C}$. Produced MDA was measured with LP reagent, as described above. Final results were calculated by the difference between sample and control, and were expressed as the hydroxyl radical quantity.

The quantity of GSH was determined with Ellman reagent $(\mathrm{DTNB}){ }^{21}$ The tissue $(0.5 \mathrm{~g})$ was homogenized with $4 \mathrm{~mL}$ of 5\% TCA and centrifuged for $10 \mathrm{~min}$ at 4000 $\times g$. Supernatant $(100 \mu \mathrm{L})$ was added to reaction medium containing $2 \mathrm{~mL}$ TRIS buffer (0.4 M, pH 8.9) and $100 \mu \mathrm{L}$ DTNB (6 mM, dissolved in methanol). Absorbance was read at $412 \mathrm{~nm}$ after $5 \mathrm{~min}$ and the results were expressed as $\mu \mathrm{mol} \mathrm{GSH} / \mathrm{mg}$ protein.
Antioxidant capacity was determined by free radical scavenging capacity and FRAP (Ferric Reducing Antioxidant Power) test.

Free radical scavenging capacity was determined using $90 \mu \mathrm{M}$ DPPH (1,1-diphenyl-2-picrylhydrasyl) rad$\mathrm{ical}^{22}$ At first, the proteins were precipitated with $20 \%$ TCA. Afterwards, there were mixed $200 \mu \mathrm{L}$ of sample and $2 \mathrm{~mL}$ of DPPH and the absorbance was read at $515 \mathrm{~nm}$ after $30 \mathrm{~min}$. Scavenging capacity was calculated by Eq 1:

Inhibition $(\%)=\left(\mathrm{A}_{\text {control }}-\mathrm{A}_{\text {sample }}\right) / \mathrm{A}_{\text {control }} \times 100 \%$

where control was without sample and presented $100 \%$ of radical content. The concentration of the homogenate that inhibits $50 \%$ of the DPPH radical was defined as $\mathrm{IC}_{50}$ value.

FRAP test was performed according to the method of Benzie and Strain (1999), ${ }^{23}$ measuring the total antioxidant potential of the sample through the reduction of ferric ions $\left(\mathrm{Fe}^{3+}\right)$ to ferrous ions $\left(\mathrm{Fe}^{2+}\right)$. FRAP reagent was consisted of $300 \mathrm{mM}$ acetate buffer pH 3.6, $10 \mathrm{mM}$ TPTZ dissolved in $40 \mathrm{mM} \mathrm{HCl}$, and $20 \mathrm{mM} \mathrm{FeCl}_{3}$ mixed in ratio 10:1:1. The volume of $100 \mu \mathrm{L}$ of sample was added to $2 \mathrm{~mL}$ of FRAP reagent and the absorbance was read at $593 \mathrm{~nm}$ after 5 min. Results were expressed as FRAP units. FRAP unit is equal to the concentration of $100 \mu \mathrm{mol} / \mathrm{L} \mathrm{Fe}^{2+}$.

\section{6. Plant Extracts Polyphenol Characterization by HPLC-PDA Method}

Separation and identification of polyphenol compounds were performed using the reversed phase high preasure liquid chromatography (RP-HPLC) with a photodiode array (PDA) detector. The spectra were acquired in the range 190-600 $\mathrm{nm}$ and chromatograms were plotted at $280 \mathrm{~nm}$ (hydroxybenzoic acids), $320 \mathrm{~nm}$ (hydroxycinnamic acids), $350 \mathrm{~nm}$ (flavonoids). The results were expressed as $\mu \mathrm{g}$ of the polyphenol compound per $\mathrm{mL}$ of the extract. For the flavonoid derivatives calibration curve of corresponding flavonoid glucoside was used for calculation and derivatives of hydroxycinnamic acids were calculated as corresponding aglycones. ${ }^{24}$ The compounds were identified by comparing the retention time, and UV-Vis spectra with appropriate standards and literature data. Quercetin derivatives had absorption maximum at 356 $\mathrm{nm}$, apigenin derivatives at $338 \mathrm{~nm}$, and luteolin derivatives at $347 \mathrm{~nm} .{ }^{25}$

\section{7. Statistical Analysis}

All determinations were performed in triplicate. Data were expressed as mean \pm standard error (SE). Values are given as means for ten mice. For statistical evaluation of data Statistica 12 software (StatSoft Inc., USA) was used. Statistical significance of differences between means was tested by Duncan's multiple range test $(p<0.05)$. 


\section{Results and Discussion}

The results of the antioxidant enzymes SOD and CAT activities in mice brain tissue are presented in Figure 1a and $1 \mathrm{~b}$, respectively. The only favorable and the highest SOD activity was observed after corn silk treatment (2.78 $\mathrm{U} / \mathrm{mg}$ protein). SOD isoenzymes play an important role in cerebral ischemia, particularly in reperfusion injury when brain cells are resupplied with oxygen that leads to overproduction of ROS and LP process. Therefore, altering SOD activity can reduce neurotoxicity. ${ }^{26}$ Bearberry extract treatment elevated CAT activity (1.17 U/mg protein), but more effective was the influence of corn silk extract (1.92 $\mathrm{U} / \mathrm{mg}$ protein).
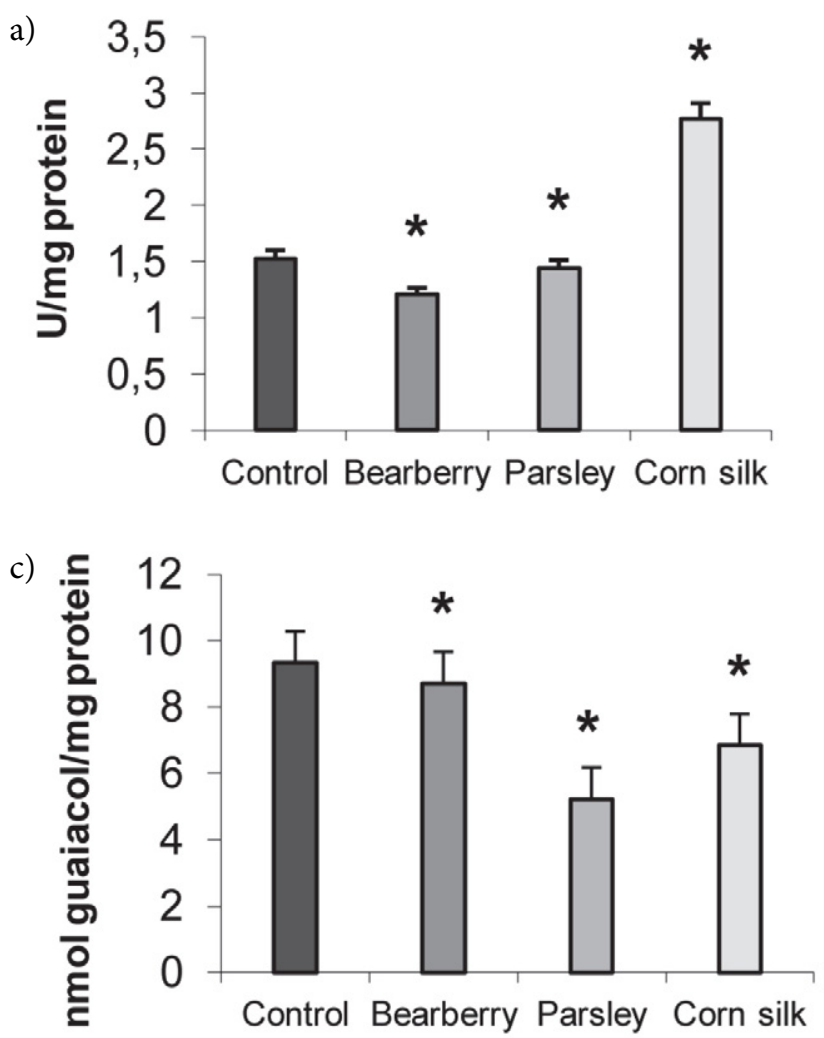

bolic stress, it is important that all scavenging mechanisms are active ${ }^{27}$, which was achieved by corn silk extract in our experiment.

The effect of investigated medicinal plant extracts on soluble protein and GSH content in mice brain is shown in the Figure $2 \mathrm{a}$ and $2 \mathrm{~b}$. In comparison with the control $(104.0 \mathrm{mg} / \mathrm{g})$, protein content was significantly decreased after corn silk treatment $(55.21 \mathrm{mg} / \mathrm{g})$, while after bearberry extract treatment it was elevated $(114.41 \mathrm{mg} / \mathrm{g})$.

In mice brains treated with corn silk and parsley (162.53 and $89.59 \mathrm{nmol} \mathrm{GSH} / \mathrm{mg}$ protein) quantities of GSH were above the control value $(77.65 \mathrm{nmol} \mathrm{GSH} / \mathrm{mg}$ protein, Figure $2 b$ ). The increase of GSH quantity is favorable for oxidative stress protection because of its role in peroxide

b)

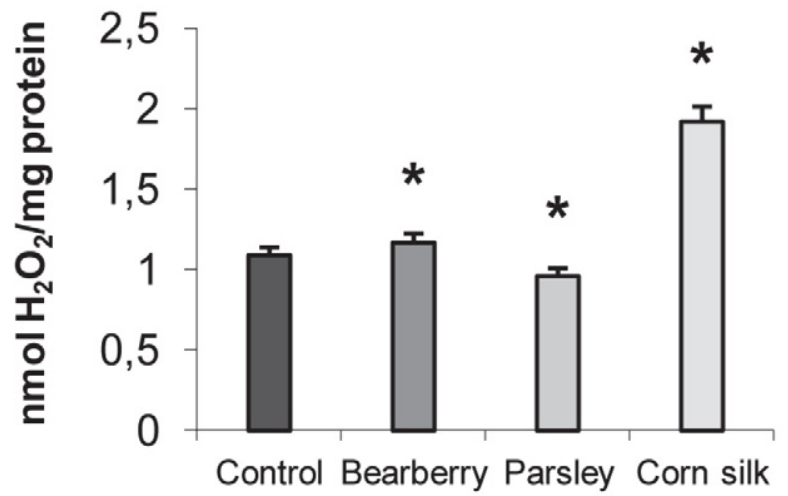

d)

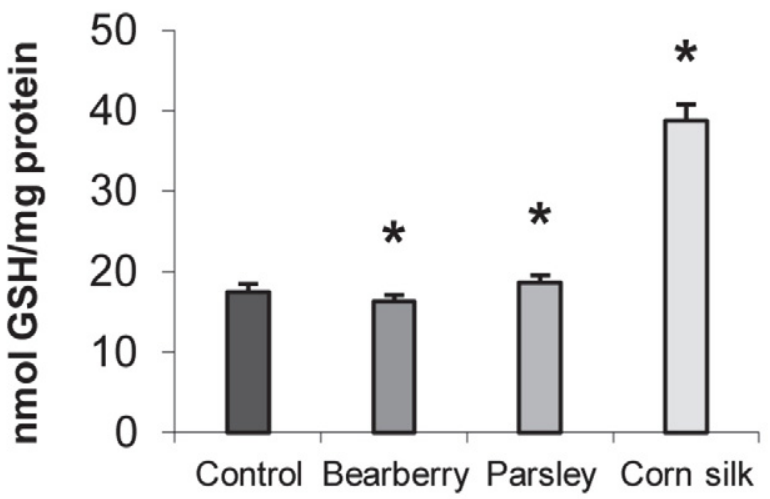

Figure 1. The activity of antioxidant enzymes SOD (a), CAT (b), GPx (c) and GSH-Px (d) in mice brain after the plant extract treatment. ${ }^{*}$ Marked values significantly differ from control according to the Duncan's multiple range test results $(p<0.05)$.

The results presented in Figure 1c show that GPx activity in mice brain tissue decreased under the influence of all studied plant extracts. The lowest enzyme activity was obtained after the parsley extract intake $(5.22 \mathrm{nmol}$ guai$\mathrm{acol} / \mathrm{mg}$ protein). In comparison to the control and to the other examined extracts, corn silk extract significantly enhanced the activity of GSH-Px $(38.78 \mathrm{nmol} \mathrm{GSH} / \mathrm{mg}$ protein, Figure 1d). Mice GSH-Px activity is very important for the detoxification of $\mathrm{H}_{2} \mathrm{O}_{2}$ in brain cells in physiological conditions. It was proved that if GSH-Px is inhibited, CAT compensates its activity and vice versa, but in meta- detoxification, as it is the substrate of the GSH-Px enzyme. Also, as an endogenous molecular antioxidant, it is important for neutralizing other reactive species. Thus, GSH is very important for intracellular redox status maintenance. ${ }^{28}$

Table 1 shows DPPH free radical scavenging activity and the ability of ferric ion reduction (FRAP test) of the brain tissue of treated animals. Radical scavenging capacity was improved under the bearberry and parsley leaf treatment, while the effect of corn silk extract was at the control level. FRAP values were improved after treatments with all examined medicinal plant extracts. 

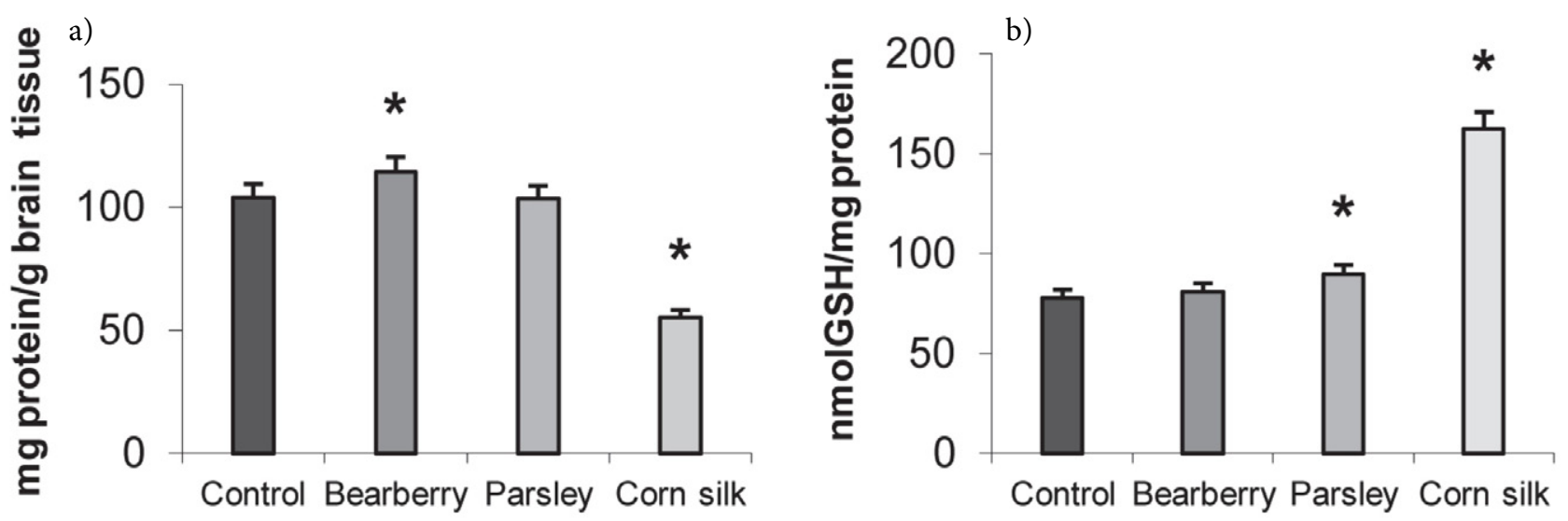

Figure 2. The soluble protein content (a) and reduced gluthatione content (GSH; b) in mice brain after the plant extract treatment. ${ }^{*}$ Marked values significantly differ from control according to the Duncan's multiple range test results $(p<0.05)$.

Table 1. DPPH radical scavenging capacity and ferric reducing antioxidant power (FRAP) of brain cells after the plant extract treatment

\begin{tabular}{lcc}
\hline Sample & DPPH $\left(\mathbf{I C}_{\mathbf{5 0}}, \mathbf{~} \mathbf{m g} / \mathbf{m L}\right)$ & FRAP units \\
\hline Control & $31.40 \mathrm{a}$ & $33.30 \mathrm{a}$ \\
Bearberry & $27.13 \mathrm{~b}$ & $36.23 \mathrm{~b}$ \\
Parsley & $29.52 \mathrm{ab}$ & $36.41 \mathrm{~b}$ \\
Corn silk & $30.86 \mathrm{a}$ & $36.52 \mathrm{~b}$ \\
\hline
\end{tabular}

Values with the different letters are significantly different according to Duncan's multiple range test results $(\mathrm{p}<0.05)$.

DPPH and FRAP tests are used for overall antioxidant potential assessment. Concerning the damages induced by free radicals and other highly reactive species, the increase of the antioxidant power of the cells is crucial to prevent different diseases. ${ }^{29}$ Our results show that there are no significant differences among the effects of examined plant extracts and that all of them induced slightly better antioxidant status of brain cells in comparison to the control. It could be possibly achieved by the promoted activity of endogenous antioxidants or by the action of polyphenol compounds present in the extracts. Plants rich in flavonoid compounds, like plants examined in our study (Table 1), promote DPPH free radical scavenging activity. ${ }^{30}$

The effects of medicinal plant extracts on ${ }^{\circ} \mathrm{OH}$ scavenging activity and level of LP in mice brains are shown in Figure 3.

A significant decrease in ${ }^{\circ} \mathrm{OH}$ accumulation was observed in the brain tissue of mice drinking all three herb extracts (Figure 3a). Hydroxyl radical is one of the most harmful reactive species because of its high reactivity, small size and easy transport through cell compartments. It attacks proteins, DNA, lipids and carbohydrates leading to their dysfunctions and severe tissue damages. Since it initiates $\mathrm{LP}$, potential of scavenging ${ }^{\circ} \mathrm{OH}$ is very important for brain cells, because lipids are responsible for normal structure and function of neural membranes. ${ }^{31}$

The LP in brain cells of mice drinking medicinal plant extracts was at the lower level than in the control group of animals. Accumulation of MDA, the product of LP, was significantly reduced under the influence of corn silk and parsley extract (1.09 and $1.43 \mathrm{nmol} \mathrm{MDA} / \mathrm{mg}$ protein, Figure $3 b)$. Brain cells are rich in polyunsaturated fat- a)

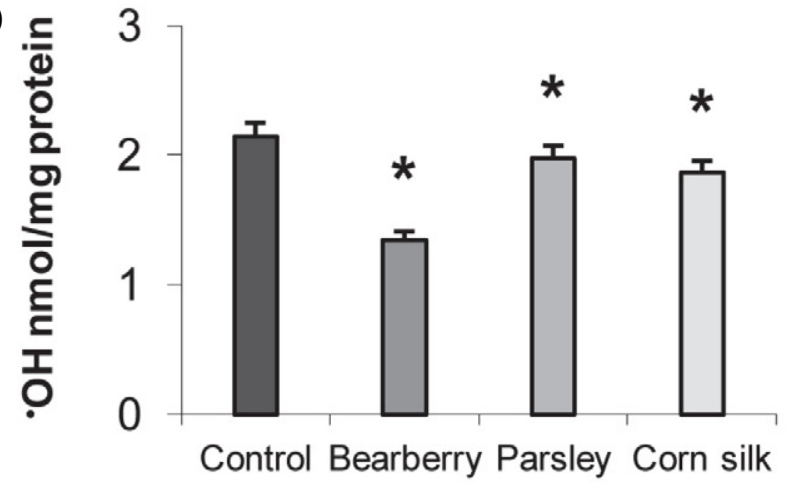

b)

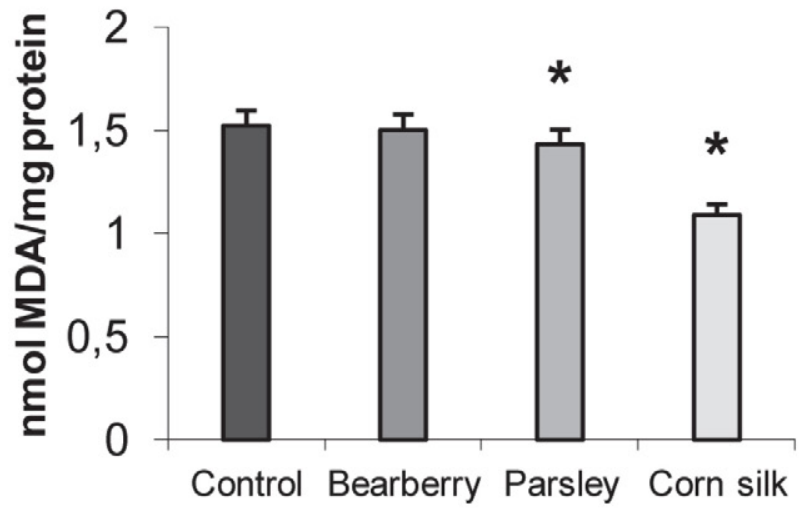

Figure 3. Hydroxyl radical scavenging activity (a) and level of lipid peroxidation (b) in mice brain after the plant extract treatment. ${ }^{*}$ Marked values significantly differ from control according to the Duncan's multiple range test results $(p<0.05)$. 
ty acids, which are very susceptible to LP, so the decrease of LP is very important, also because many neurological disorders, like Alzheimer's, Parkinson's, Huntington disease, schizophrenia, and many CNS traumas, involve dysfunction of lipid metabolism. ${ }^{31}$

All examined extracts were rich in phenolic content (Table 2) and phenolic compounds are generally known for their strong antioxidant activities, therefore they could be responsible for the decrease of LP in mice brain. ${ }^{32}$

Polyphenol profile of medicinal plant extracts investigated in this study is presented in Table 2.

Table 2. Polyphenol compounds content in plant extracts.

\begin{tabular}{llll}
\hline Polyphenol compound & $\begin{array}{l}\text { Bearberry } \\
\text { leaves } \\
\boldsymbol{\mu g} / \mathbf{m L} \\
\text { extract }\end{array}$ & $\begin{array}{l}\text { Parsley } \\
\text { leaves } \\
\boldsymbol{\mu g} / \mathbf{m L} \\
\text { extract }\end{array}$ & $\begin{array}{l}\text { Corn } \\
\text { silk } \\
\boldsymbol{\mu g} / \mathbf{m L} \\
\text { extract }\end{array}$ \\
\hline Gallic acid & 162.99 & 4.14 & 3.16 \\
Protocatechuic acid & - & 2.69 & 1.20 \\
Catechin & - & 51.60 & - \\
p-Hydroxybenzoic & - & 0.42 & 0.69 \\
Vanilic acid & - & - & 1.63 \\
Syringic acid & 20.02 & - & - \\
p-Coumaric acid derivative & - & - & 0.75 \\
p-Coumaric acid & - & 7.53 & 1.47 \\
Ferulic acid derivative & - & - & 2.40 \\
Ferulic acid & - & - & 5.94 \\
Quercetin derivatives & 208.74 & - & - \\
Quercetin & 4.16 & - & - \\
Kaempferol derivatives & - & 211.80 & - \\
Apigenin 7-glucoside & - & 491.97 & - \\
Apigenin derivative & - & 192.44 & - \\
Apigenin & - & 0.22 & - \\
Luteolin 7-glucoside & - & - & 31.93 \\
Luteolin derivatives & - & - & 584.07 \\
Luteolin & - & - & 35.34 \\
TOTAL & 395.91 & 962.80 & 668.58 \\
\hline
\end{tabular}

The polyphenol profile and content varies among the plant extracts, but all of them were pointed out with high flavonoid content, although flavonoid subgroups differ. Parsley and corn silk were rich in flavones. Apigenin derivatives predominated in parsley, while in corn silk extract the most dominant were luteolin derivatives. Flavonols, in particular, quercetin derivatives, were present in bearberry leaf extract, and kaempferol derivatives were present in parsley leaf extract.

Quercetin and galloyl derivatives, as well as other phenolic constituents, were found in bearberry leaves. ${ }^{33}$ Within the same species phenolic content could vary due to many factors, including instrinsic biological or environmental factors. Aside from the most abundant bearberry phenolic glycoside arbutin, the contents of quercetin glucoside, myricetin, catechin, and caffeic acid showed geographic and climatic dependance. ${ }^{34}$ Although our results showed no significant effect of bearberry leaves on lipid peroxidation in mice brain, bearberry leaves extract in vitro delayed lipid oxidation showed due to its antioxidant activity and scavenging ability. ${ }^{35}$ Very high contribution of phenolic content to antioxidant capacity of bearberry leaves was established. ${ }^{36}$

De Menezes Epifanio at al. (2020) identified 30 different flavonoid glycosides in parsley leaves and showed that the antioxidant potential was directly related to the synergistic effect of all constituents present in the extract. Further, they proved that, unlike apigenin, its glycosylated derivative, apiin, could protect cells from oxidative stress caused by hydrogen peroxide. ${ }^{37}$

Similarly to our results, cinnamic acids derivatives and luteolin derivatives were shown to be the most dominant phenolic constituents of corn silk..$^{38,39}$ Wang et al. (2019) identified 76 phenolic compounds in corn silk aqueous extract, and shown that, after oral administration, phenolic compounds were metabolized and reached the blood predominantly in the forms of glucuronide conjugates. ${ }^{40}$ Conjugation/deconjugation process in organism presents the key process that allows phenolic compounds to circulate through the organism and express their activities. ${ }^{41}$

Our results suggest that luteolin derivatives from corn silk extract may be responsible for the very potent reducing capacity of corn silk extract and protection against LP. Many studies showed strong antioxidant activities of corn silk extracts. ${ }^{42}$ Flavon compounds from corn silk showed better LP inhibition activity, and radical scavenging capacity than commercially used antioxidants. ${ }^{43}$ Besides, maysin, luteolin derived flavone from corn silk, was shown to possess neuroprotective effects. ${ }^{44}$ Polyphenol compounds from examined plant extracts could also induce higher antioxidant response which led to a better $\cdot \mathrm{OH}$ scavenging activity in the brains of animals that were subjected to the treatments.

\section{Conclusion}

The intake of corn silk, parsley leaf and bearberry leaf extracts affected the metabolism of mice brain tissue. Corn silk showed a significant positive effect on activities of antioxidant enzymes SOD, CAT, and GSH-Px. The quantity of GSH was the highest under the influence of corn silk extract, while the accumulation of $\cdot \mathrm{OH}$ and MDA was the lowest, suggesting its protective effect against LP. Parsley leaf extract induced the increase in GSH content and the decrease in ${ }^{\circ} \mathrm{OH}$ and MDA accumulation. Bearberry leaf extract induced CAT activity and the decrease in the accumulation of ${ }^{\circ} \mathrm{OH}$, while MDA accumulation was maintained at the control level. All three plant extracts were rich in polyphenol compounds, especially in flavonoids, which may be responsible for beneficial effects. Our results support the use of these medicinal plants as natural antioxidants in the prevention of oxidative stress provoked 
damages of brain tissue, but further investigations are required to clarify their mechanisms of action.

\section{Acknowledgment}

This research was funded by the Ministry of Education, Science and Technological Development, Republic of Serbia, Contract No. 451-03-9/2021-14/200117

\section{Conflicts of Interest}

The authors declare that they have no conflict of interest.

\section{References}

1. L. M. Haces, T. L. Montiel, L. Massieu, Neurosci. J. 2010, 165, 28-38. DOI: 10.1016/j.neuroscience.2009.10.003

2. G. P. Marrazzo, P. Bosco, F. La Delia, Neurosci. Lett. 2011, 504: 252-256. DOI: 10.1016/j.pmpp.2008.04.002

3. M. Bains, E. D. Hall, Biochim. Biophys. Acta, Mol. Basis Dis. 2012, 1822: 675-684. DOI: 10.1016/j.bbadis.2011.10.017

4. T. S. Anthonymuthu, E. M. Kenny, H. Bayır, Brain. Res. 2016,1640(Pt A), 57-7. DOI: 10.1016/j.brainres.2016.02.006

5. A. Kumar, D. J. Loane, Brain. Behav. Immun. 2012, 26, 11911201. DOI: 10.1016/j.bbi.2012.06.008

6. L. B. Ceretta, G. Z. Réus, H. M. Abelaira, K. F. Ribeiro, G. Zappellini, F. F. Felisbino, A. V. Steckert, F. Dal-Pizzol, J. Quevedo, J. Diabetes. Res. 2012, Article ID 302682,

DOI: $10.1155 / 2012 / 302682$

7. J. C. Hanish Singh, V. Alagarsamy, S. Sathesh Kumar, Y. Narsimha Reddy, Willd. Phytother. Res. 2011, 25, 1061-1067. DOI: $10.1016 /$ j.jep.2011.08.048

8. D. Štajner, B. M. Popović, J. Čanadanović-Brunet, S. Đilas, G. Cetković, LWT-Food Sci. Technol. 2014, 55, 408-413.

DOI: $10.1016 /$ j.lwt.2013.08.025

9. D. Štajner, B. M. Popović, D. Čalić, M. Štajner, Sci. World. J. 2014, 7 pages, DOI:10.1155/2014/767392 -b.

10. M. J. Engelhart, M. I. Geerlings, A. Ruitenberg, J. C. van Swieten, A. Hofman, J. C. Witteman, M. M. Breteler, JAMA, 2002, 287(24): 3223-3229. DOI: 10.1001/jama.287.24.3223

11. B. Hua, H. Chunx, X. Miaomiao, L. Xin, L. Rui, Plant Food Hum. Nutr. 2010, 65(3), 271-276.

DOI: $10.1007 / \mathrm{s} 11130-010-0172-6$

12. H. Jia, W. Aw, M. Hanate, S. Takahashi, K. Saito, H. Tanaka, M. Tomita, H. Kato, J. Funct. Foods. 2014, 11, 438-448.

DOI: $10.1016 /$ j.jff.2014.09.018

13. M. Vranješ, B. M. Popović, D. Štajner, V. Ivetić, A. Mandić, D. Vranješ, J. Funct. Foods. 2016, 21, 272-282.

DOI: $10.1016 /$ j.jff.2015.12.016

14. S. Mandal, A. Mitra, N. Mallick, Physiol. Mol. Plant Path. 2008, 72, 56-61. DOI: 10.1016/j.pmpp.2008.04.002

15. T. Iwase, A. Tajima, S. Sugimoto, K. Okuda, I. Hironaka, Y. Kamata, K. Takada, Y. Mizunoe, Sci. Rep. 2013, 3, 3081.

DOI: $10.1038 /$ srep03081
16. I. Morkunas, J. Gmerek, J. Plant. Physiol. 2007, 164, 185-194. DOI: 10.1016/j.jplph.2005.11.005

17. R. Ždero Pavlović, B. Blagojević, D. Latković, D. Agić, N. Mićić, D. Štajner, B. M. Popović, Baltic Forestry, 2020, 26(2), 420. DOI: $10.46490 / \mathrm{BF} 420$

18. D. Štajner, B. M. Popović, D. Ćalić-Dragosavac, Đ. Malenčić, S. Zdravković-Korać, Phytother. Res. 2011, 25(11), 16181622. DOI: $10.1002 /$ ptr.3394

19. J. K. Moon, T. Shibamoto, J. Agric. Food Chem. 2009, 57, 1655-1666. DOI: $10.1021 / \mathrm{jf} 803537 \mathrm{k}$

20. J. M. Gardner, S. D. Aust, J. Cataract Refractive Surg. 2009, 35(12), 2149-2153. DOI: 10.1016/j.jcrs.2009.06.030

21. D. Štajner, B. M. Popović, P. Boža, Phytother. Res. 2007, 21(12), 1242-1245. DOI: $10.1002 /$ ptr.2244

22. J. Čanadanović-Brunet, G. Ćetković, V. Tumbas Šaponjac, S. Stajčić, S., J. Vulić, J., S. Djilas, D. Štajner, B. Popović, Ind. Crops Prod. 2014, 62, 1-7. DOI: 10.1016/j.indcrop.2014.08.009

23. I. F. F. Benzie, J. J. Strain, Methods. Enzymol. 1999, 299, 1527. DOI: $10.1016 / S 0076-6879(99) 99005-5$

24. B. Popović, B. Blagojević, R. Ždero Pavlović, N. Mićić, S. Bijelić, S. Bogdanović, A. T. Serra, Food Chem. 2020, 302:125373. DOI: $10.1016 /$ j.foodchem.2019.125373

25. T. Mabry, K. R. Markham, M. B. Thomas: The systematic identification of flavonoids. Springer Science \& Business Media, 2012, pp. 35-57.

26. S. Fukui, T. Ookawara, H. Nawashiro, K. Suzuki, K. Shima, Free Rad. Biol. Med. 2002, 32, 289-298.

DOI: $10.1016 /$ S0891-5849(01)00804-8

27. P. Klivenyi, O. A. Andreassen, R. J. Ferrante, N. Dedeoglu, G. Mueller, E. Lancelot, M. K. Bogdanov, J. K. Andersen, D. Jiang, M. F. Beal, J. Neurosci. 2000, 20, 1-7.

DOI: 10.1523/JNEUROSCI.20-01-00001.2000

28. F. Favilli, T. Iantomasi, M. Marraccini, M. Stio, B. Lunghi, C. Treves, M. T. Vincenzini, Neurobiol. Aging 1994, 15(4), 429433. DOI: $10.1016 / 0197-4580(94) 90074-4$

29. I. Álvarez-González, F. Fernando Garcia-Melo, V. R. VásquezGarzón, A. E. Saúl Villa-Treviño, O. Madrigal-Santillán, J. A. Morales-González, J. A. Mendoza-Peres, E. Madrigal-Bujaidar, Evid. Based Complement. Alternat. Med. 2014, Article ID 379890, 8 pages. DOI: 10.1155/2014/379890

30. I. Baranowska, S. Bajkacz, Food Chem. 2018, 256, 333-341. DOI: $10.1016 /$ j.foodchem.2018.02.138

31. R. M. Adibhatla, J. F. Hatcher, Future Lipidol. 2007, 2(4), 403422. DOI: $10.2217 / 17460875.2 .4 .403$

32. A. Scalbert, I. T. Johnson, M. Saltmarsh, Am. J. Clin. Nutr. 2005, 81, 215S-217S. DOI: 10.1093/ajcn/81.1.215S

33. M. Wrona, S. Blasco, R. Becerril, C. Nerin, E. Sales, E. Asensio, Talanta, 2019, 196, 498-509.

DOI: 10.1016/j.talanta.2018.12.057

34. E. Asensio, D. Vitales, I. Pérez, L. Peralba, J. Viruel, C. Montaner, J. Vallès, T. Garnatje, E. Sales, Plants 2020, 9(9), 1250. DOI: $10.3390 /$ plants 9091250

35. N. A. Mohd Azman, M. G. Gallego, F. Segovia, S. Sureena Abdullah, S. M. Shaarani, M. P. Almajano Pablos, Antioxidants 2016, 5(11), 11 .

DOI: $10.3390 /$ antiox 5020011 
36. X. C. Song, E. Canellas, E. Asensio, C. Nerín, Talanta, 2020, 213, 120831. DOI: 10.1016/j.talanta.2020.120831

37. N. M. de Menezes Epifanio, L. R. I. Cavalcanti, K. F. Dos Santos, P. S. C. Duarte, P. Kachlicki, M. Ożarowski, C. J. Riger, D. S. de Almeida Chaves, Food Funct. 2020, 11(6), 5346-5356. DOI: $10.1039 / \mathrm{d} 0$ fo00484g

38. S. Žilić, M. Janković, Z. Basić, J. Vančetović, V. Maksimović, J. Cereal Sci. 2016, 69, 363-370. DOI: 10.1016/j.jcs.2016.05.003

39. J. Tian, H. Chen, S. Chen, L. Xing, Y. Wang, J. Wang, Food Funct. 2013, 10, 1526-1534. DOI: 10.1039/C3FO60171D
40. Y. Wang, Q. Liu, S. Fan, X. Yang, L. Ming, H. Wang, J. Liu, J. Sep. Sci. 2019, 42(19), 3054-3066.

DOI: $10.1002 /$ jssc.201900407

41. F. Perez-Vizcaino, J. Duarte, C. Santos-Buelga, J. Sci. Food Agric. 2012, 92(9), 1822-1825. DOI: 10.1002/jsfa.5697

42. K. Hasanudin, P. Hashim, S. Mustafa, Molecules 2012, 17(8), 9697-9715. DOI: 10.3390/molecules 17089697

43. S. C. Ren, Q. Q. Qiao, X. L. Ding, Czech J. Food Sci. 2013, 31(2), 148-155.

44. D. J. Choi, S. L. Kim, J. W. Choi, Y. I. Park, Life Sci. 2014, 109(1), 57-64. DOI: 10.1016/j.lfs.2014.05.020

\section{Povzetek}

Ta raziskava je bila izvedena $\mathrm{z}$ namenom proučitve učinkov zdravilnih rastlinskih izvlečkov koruznih laskov (Stigma maydis), peteršiljevih listov (Petroselini folium) in listov vednozelenega gornika (Uvae ursi folium) na antioksidativni status možganov poskusnih živali (miši) pod fiziološkimi pogoji. Biološke lastnosti teh rastlin niso dovolj raziskane, zato je bil cilj raziskati njihove možne antioksidativne učinke, ki bi lahko ublažili oksidativne poškodbe možganskega tkiva. Izvleček koruznih laskov je pozitivno vplival na delovanje antioksidativnih encimov v možganskem tkivu miši. Ekstrakt peteršilja je spodbudil povečanje vsebnosti glutationa in zmanjšal lipidno peroksidacijo. Izvleček listov vednozelenega gornika je spodbudil povečanje aktivnosti katalaze in zmanjšanje vsebnosti hidroksilnih radikalov, medtem ko se je kopičenje malonildialdehida ohranjalo na ravni kontrole. Rezultati, pridobljeni v tej raziskavi, podpirajo uporabo koruznih laskov, listov peteršilja in vednozelenega gornika kot naravnih virov antioksidantov pri preprečevanju in zdravljenju poškodb možganskega tkiva in različnih bolezni, ki jih povzroča oksidativni stres.

Except when otherwise noted, articles in this journal are published under the terms and conditions of the Creative Commons Attribution 4.0 International License 